\title{
Perkembangan Pemukiman Di Daerah Indramayu
}

\author{
Nanang Saptono
}

Keywords: settlement, West Java, north coast of Java, origin, history, city

\section{How to Cite:}

Saptono, N. Perkembangan Pemukiman Di Daerah Indramayu. Berkala Arkeologi, 15(3), 60-64. https://doi.org/10.30883/jba.v15i3.671

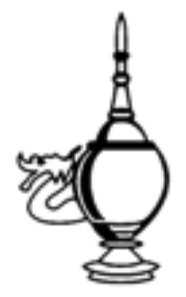

\section{Berkala Arkeologi}

https:// berkalaarkeologi.kemdikbud.go.id/

Volume 15 No. 3, 1995, 60-64

DOI: $10.30883 /$ jba.v15i3.671

This work is licensed under a Creative Commons Attribution-NonCommercialShareAlike 4.0 International License. 


\title{
PERKEMBANGAN PEMUKIMAN DI DAERAH INDRAMAYU
}

\author{
Nanang Saptono \\ (Balai Arkeologi Bandung)
}

Pemukiman merupakan suatu tempat manusia hidup dan melakukan aktivitas kehidupan. Pemukiman dapat diwujudkan dalam berbagai benuk salah satu di antaranya berupa kota. Pengertian suatu kota, hingga saat ini belum ada suatu batasan yang diterapkan secara universal. Pada kebudayaan yang berbeda-beda, elemen-elemen yang berbeda telah digunakan sebagai persyaratan minimum bagi sebuah pemukiman untuk da-pat disebut sebagai kota (Rapoport,1986:22). Keanekaragaman pengertian kota disebabkan pula karena perkembangan zaman yang mengakibatkan terjadinya perubahan. Perubahan tersebut disesuaikan dengan kemampuan manusia dan tata geografi daerahnya. Bentuk-bentuk lahan tertentu memiliki lingkungan biotik maupun abiotik yang menguntungkan bagi kehidupan manusia. Faktorfaktor yang menguntungkan tersebut antara lain Ialah topografi rata, keadaan tanah subur, mudah memperoleh air permukaan atau air tanah, mudah berkomunikasi dengan luar, serta terhindar dari serangan musuh (Hadisumamo, 1985:2).

Pada masa prasejarah, ketika sistem bercocok tanam mulai dikenal, manusia mulai bertempat tinggal secara menetap di suatu tempat. Mereka bermukim secara mengelompok di tempattempat yang keadaan alamnya dapat memenuhi kehidupan, misalnya di gua-gua yang dekat dengan sumber makanan atau tempat-tempat terbuka di pinggir pantai (Soejono,1990:155-156). Pada masa berikutnya, ketika hubungan dengan orang-orang asing mulai dilakukan, barulah muncul kota-kota dalam arti yang sesungguhnya. Pada masa klasik muncul beberapa kota baik di pesisir maupun di pedalam. Beberapa kota di pe-sisir utara Jawa kebanyakan merupakan pela-buhan dagang yang cukup ramai. Kota tersebut misalnya Hujung Galuh dan Tuban. Kota di peda-laman misalnya kota Majapahit yang sisa-sisanya dapat ditemukan di daerah Trowulan. Kemudian pada masa perkembangan Islam, ketika itu pra-sarana dan sarana transportasi mengalami perkembangan pesat, muncul kota-kota di sepan-jang pantai (Tjandrasasmita, 1984:121-30).

Di pantai utara Jawa Barat, salah satu kota yang berkembang dari masa klasik hingga masa Islam yaitu Indramayu. Kota itu sudah disebut sejak masa Kerajaan Sunda. Pada masa sekarang. berstatus sebagai ibukota kabupaten. Dalam rentang waktu yang sangat panjang, kota Indramayu mengalami pasang dan surut. Dalam makalah ini akan dicoba-ungkapkan perkembangan pemukiman di daerah Indramayu berdasarkan data hasil penelitian Balai Arkeologi Bandung pada bulan Juli 1994 yang lalu. Dengan demikian, karena masih terbatasnya data, pengungkapannya bersi-fat pendahuluan

\section{Sejarah Singkat}

Awal pertumbuhan kota-kota di sepanjang pantai utara Jawa Barat erat kaitannya dengan jatuhnya Malaka ke tangan Portugis pada tahun 1511. Sejak itu hubungan dagang antara Portugis dengan kerajaan Sunda semakin intensif. Hal ini karena Sunda banyak menyediakan barang-barang komoditas terutama lada. Dalam uraiannya, Barros memberi gambaran bahwa daerah pedalaman Sunda bergunung-gunung tidak seperti di pedalaman Jawa. Pelabuhan-pelabuhan yang utama berjumlah enam yaitu Chiamo, Xaca-tra, atau Caravam, Tangaram, Cheguide, Pon-dang, dan Bantam (Djajadiningrat, 1983:83). Menurut Tomé Pires, Pelabuhan Sunda yang penting yaitu Cimanuk, Kalapa, Tamgara, Cigede, Pontang, dan Banten. Ibukota kerajaan disebut Dayo yang terletak di pedalaman (Cortessao, 1944:170). Kota pelabuhan tersebut dapat diidentifikasikan dengan beberapa kota yang ada sekarang. Cimanukiadalah Indramayu sekarang yang terletak di ujung timur Jawa Barat. Kalapa adalah Sunda Kelapa, Tamgara atau Tangaram kemungkinan Tangerang atau Tonare sekarang. Cigede adalah Cikande, Pondang atau Pontang adalah Pontang di daerah Teluk Banten, sedangkan Bantam merupakan Banten sekarang. Dari keenam pelabuhan tersebut, kebanyakan terletak di sekitar Teluk Banten sekarang, hanyalah Cimanuk atau Indramayu yang terletak jauh di ujung timur Jawa Barat. Antara ibukota dengan pelabuhan dihubungkan dengan jalan darat yang berpusat di Pakwan Pajajaran, yang satu menuju ke timur sedangkan yang lainnya lagi ke barat. Jalan ke timur menghubungkan Pakwan Pajajaran dengan Karangsambung yang terletak di tepi Sungai Cimanuk. Diduga jalur ini hingga ke Cirebon, Kuningan, sampai Kawali. Sedangkan jalan yang ke arah barat menghubungkan Pakwan Pajajaran hingga Banten (Sumadio, 1990:390).

Dari data sejarah tersebut dapat dilihat bahwa pemukiman di tepi Sungai Cimanuk banyak 
disebut. Hal ini tidak mengherankan karena kerajaan Sunda ketika beribukota di Kawali dan Galuh daerah Ciamis, banyak menggantungkan prasarana transportasi menuju pantai pada Sungai Cimanuk. Menurut Babad Dermayu, perubahan nama dari Cimanuk menjadi Indramayu berkaitan erat dengan cerita wakil kerajaan Sunda (Galuh) bemama Wiralodra yang menjadi penguasa di Indramayu. Pada tahun 1527, Cimanuk melepaskan diri dari kekuasaan kerajaan Sunda dan namanya diubah menjadi indramayu (Dasuki, 1977:106). Nama Indramayu diambil dari nama istri Wiralodra Endang Darma yang juga disebut Darma Ayu. Dari nama panggilan tersebut, daerah Cimanuk kemudian disebut Dermayu yang akhirnya jadi Indramayu.

Surutnya kekuasaan kerajaan Sunda digantikan oleh Banten di daerah barat Jawa Barat dan Cirebon di daerah timur Jawa Barat. Pada masa ini Indramayu menjadi daerah kekuasaan Cirebon hingga masa kolonial, Indramayu dibawah kontrol residen Cirebon (Abdurachman, 1982:29-67)

\section{Pemukiman Di Daerah Indramayu}

Data arkeologis yang merupakan indikator pemukiman di daerah Indramayu berupa topo-nim, bangunan-bangunan kuna, dan data arkeo-logis yang bersifat artefaktual. Berikut akan di-uraikan secara singkat hasil penelitian yang dila-kukan Balai Arkeologi Bandung (Saptono, 1994).

\subsection{Kecamatan Indramayu \\ a. Desa Pabean}

Desa ini terletak di sekitar muara aliran Sungai Cimanuk dan merupakan bagian paling uta-ra Kabupaten Indramayu. Nama Pabean merupa-kan toponim yang menunjukkan bekas pabean. Di daerah ini terdapat "makam" yang oleh pendu-duk setempat diceritakan sebagai petilasan Syech Datuk Khapi dalam rangka menyebarkan Islam di daerah Pabean. Menurut carita Purwaka Caruban Nagari, Syekh Datuk Khapi disebut pula Syekh Nurjati/Syekh Idhopi. la merupakan penda-tang dari Parsi, ketika datang di Jawa berkedudukan di Pasambangan daerah Cirebon pada tahun 1415 (Ekadjati, 1975:88; Dasuki, 1977: 50)

Keadaan petilasan yang ada sekarang berupa "makam" yang dilengkapi cungkup. Di sekitar petilasan tersebut sekarang berupa kompleks pemakaman umum bagi masyarakat setempat. Menurut cerita lisan masyarakat, di lokasi tersebut dahulu terdapat padepokan pusat islamisasi. Artefak yang ditemukan berupa fragmen keramik Cina masa dinasti Qing.

\section{b. Kelurahan Paoman}

Nama Paoman juga merupakan toponim berasal dari kata pa-omah-an. Kampung Paoman dipercaya penduduk setempat sebagai pemukiman yang dihuni para pekerja di Pabean. Kampung ini terietak di sisi timur Sungai Cimanuk. Di tengah-tengah perkampungan yang ada seka-rang terdapat petilasan Padepokan Paoman, yaitu bekas lokasi islamisasi bagi pemukim di Kampung Paoman. Petilasan tersebut berupa "makam" berjumlah sebelas sebagai lambang wali-sanga dan Ki Jaka Geding serta Ki Jaka Kendil. Di sini ditemukan fragmen keramik dari Eropa, Cina masa diniasti Ming dan Qing, serta bandul jaring

Tidak jauh dari objek tersebut, di sebelah tenggaranya terdapat sisa dam tinggalan zaman Belanda yang dibangun pada masa Daendels (1806 - 1811). Dahulu berfungsi sebagai pengatur air yang masuk Sungai Cimanuk dan beberapa kanal. Kanal yang dahulu ada, sekarang sudah diurug dan dijadikan perumahan. Di sebelah selatan dam terdapat bekas bangunan perkantoran kereta api. Sekarang bangunan tersebut berfungsi sebagai rumah tinggal. Di sebelah timur bekas bangunan perkantoran kereta api terdapat bangunan bekas stasiun kereta api yang dilengkapi beberapa bangunan gudang. Di sebelah barat bekas bangunan perkantoran kereta api terdapat bangunan bekas penggilingan padi milik Belan-da. Di daerah ini banyak ditemukan fragmen keramik Eropa dan Cina masa diniasti Qing.

\section{c. Kelurahan Lemah Abang}

Nama Lemah Abang sering dihubungkan dengan tokoh Syekh Siti Jenar yang juga disebut Syekh Lémah Abang. Di Indramayu. Syekh Siti Jenar mengembangkan ajarannya yang kemudian lókasi pusat pengembangan ajarannya dise-but Lemah Abang (Dasuki,1977:48). Di tepi Su-ngai Cimanuk sebelah timur terdapat masjid A-gung Indramayu. Masjid ini dibangun bhun 1825 pada masa pemerintahan Bupati Sosrowardoyo. Dalain pembangunannya mendapat sponsor dari seorang Cina bemana Nio Tju Tan. Masjid ini te-lah mengalami beberapa kali renovasi, yang ter-akhir pada tahun 1936/1937. Arsitektur masjid yang ada sekarang berdenah bujur sangkar beratap tajug tumpang tiga

\section{d. Kelurahan Karang Anyar dan Karang Malang}

Kelurahan Karang Anyar dan Karang Malang merupakan pusat kota indramayu. Di sepanjang ruas Jl. Jend. Suprapto pada sisi kiri dan kanan jalan merupakan pemukiman etnis Cina. Lokasi ini juga biasa disebut Kampung Pacinan. Di sini terdapat lokasi yang disebut Pasar Lawas merupakan bekas lokasi pasar. Pada tahun 1925 pasar dipindahkan 
Pemukiman etnis Cina juga terdapat di sepanjang Jl. Cimanuk hingga Jl. Veteran. Ruas jalan ini sejajar dengan Jl. Jend. Suprapto di sebelah barat dan terletak di sisi timur Sungai $\mathrm{Ci}$ manuk. Beberapa bangunan selain berfungsi sebagai rumah tinggal juga sebagai gudang. Gudang-gudang tersebut menghadap ke Sungai Cimanuk. Di sini juga terdapat bangunan klen-teng bernama An Tjeng Bio atau Vihara Dharma Rahayu. Klenteng dibangun pada tahun 1880 oleh Poey Soen Kam.

\section{e. Kelurahan Bojongsari}

Di sini terdapat suatu komplek makam yang disebut Stana Bojong Dermayu. Menurut cerita rakyat setempat, lokasi ini dahulu merupakan tempat bermukimnya para utusan dari Cirebon yang terdiri Sunan Jati Purba, Syekh Datuk Khapi, Pangeran Atas Angin, Sunan Kalijaga, Sunan Giri, dan Sunan Bonang. Para utusan tersebut dilambang-kan dengan "makam" yang terdapat pada suatu bangunan.

\subsection{Kecamatan Sindang}

Wilayah yang termasuk Kecamatan Sindang terletak di sisi barat Sungai Cimanuk. Pada beberapa desa di wilayah ini juga terdapat data sebagai indikator pemukiman.

\section{a. Desa Dermayu}

Di daerah Blok Pojok banyak terdapat sebaran gumpalan beberapa bata yang tertutup lelehan logam. Dari data ini menunjukkan bahwa di lokasi tersebut dahulu merupakan pusat in-dustri pengolahan logam. Selain itu juga banyak terdapat sebaran fragmen keramik asing.

Daerah Blok Kampung Arab merupakan pemukiman etnis Arab yang sampai sekarang masih berlanjut. Di daerah ini juga banyak terdapat sebaran fragmen keramik asing. Keramik asing tersebut berasal dari Eropa dan Cina masa dinasti Qing.

Di Blok Tengah terdapat bangunan masjid kuna bernama Masjid Dermayu. Bangunan yang ada sekarang merupakan hasil renovasi yang telah dilakukan beberapa kali. Konstruksi bangu-nan utama menggunakan teknik pasak. Pada beberapa pasak dihias dengan motif padma mu-la dan nanasan. Bagian atap masjid dilengkapi mustaka berbentuk limas terbalik dari bahan terakota. Masjid ini diperkirkan sudah berumur lebih dari 200 tahun (Dasuki, 1977:49), namun titi mangsa tegas yang memberi tanda pendirian masjid tidak ada. Di masjid ini masih tersimpan mimbar kuna yang sekarang sudah tidak dipergunakan. Mimbar dihias sulur-suluran dan pada bagian sandaran berhias motif wadasan.
Di belakang masjid terdapat komplek kuburan yang sampai sekarang masih dipakai. Di antara makam tersebut terdapat kelompok makam yang disebut Makam Salawe. Tokoh utama yang dimakamkan bernama Pangeran Guru berasal dari Palembang (Dasuki,1977:70). Pada salah satu nisan kelompok makam ini berhias motif Surya Majapahit.

\section{b. Desa Penganjang}

Desa Penganjang terletak di tepi barat Sungai Cimanuk bersebarangan dengan Kelurah-an Paoman, Kec. Indramayu. Di sini terdapat bangunan bekas kantor asisten residen. Bangunan bergaya Eropa menghadap ke timur atau ke arah Sungai Cimanuk. Keramik yang ditemukan berasal dari Eropa dan Cina masa dinasti Ming dan Qing. Di sebelah selatan bangunan ini pada jarak sekitar $50 \mathrm{~m}$, terdapat lahan bekas komplek kuburan Belanda. Dari beberapa nisan yang tersisa terdapat angka tahun. Angka tahun tertua 10 April 1852 dan yang termuda 24 Juli 1912.

\section{Perkembangan Pemukiman}

Salah satu teori tentang terjadinya kota menyebutkan bahwa kota dapat terbentuk mela-lui dua cara, yaitu secara spontan dan direncanakan (Hourani, 1970:9). Kota yang terbentuk secara spontan biasanya tumbuh dalam jangka waktu lama. Pertumbuhan kota tersebut didukung oleh banyak faktor antara lain geografi, ekonomi, sosial, dan potitik. Kota yang terbentuk karena direncanakan adalah kota yang dengan sengaja didirikan oleh penguasa sebagai pusat pemerintahan (Hourani, 1970:10). Kota yang demikian ini berpola teratur. Wertheim berpendapat bahwa tata kota yang dibuat secara tradisional biasanya direncanakan oleh penguasa, yaitu raja atau adipati. Pola tata kota yang demikian dapat diketa-hui dari denahnya, yaitu adanya alun-alun yang terletak di tengah kota. Bangunan-bangunan penting didirikan secara tradisional menurut empat arah mata angin. Jaringan jalan sebagai prasarana transportasi diatur saling berpotongan tegak lurus (Wertheim,1959:147). Waiaupun secara umum terdapat pola kota spontan dan direncanakan, tetapi dalam pertumbuh-annya kota spontan dapat berkembang secara terencana.

P.J.M. Nas membagi kota berdasarkan letak geografisnya (Nas, 1986: 23 - 30) yaitu kota pantai dan kota di daerah pedalaman. Masyara-kat kota pantai menitikberatkan kehidupan pada aktifitas perdagangan, akibatnya kota pantai lebih bersifat kosmopolit. Sebaliknya masyarakat kota di daerah pedalaman lebih menitikberatkan kehidupan pada bidang agraris, akibatnya lebih bersifat tradisional. Sifat yang berbeda tersebut menjadikan 
masyarakat kota pantai lebih mudah menerima pengaruh asing bila dibandingkan dengan masyarakat kota di daerah pedalaman.

Secara geografis, pemukiman di Indramayu dapat digolongkan tipe kota pantai. Tampak jelas bahwa pemukiman di Indramayu berkembang di sepanjang Sungai Cimanuk. Kemungkinan yang mula-mula berkembang adalah daerah Pabean yang letaknya paling dekat dengan pesisir. Berdasarkan data sejarah, sebelum disebut Indramayu lebih dikenal dengan sebutan Cimanuk (Chiamo). Sebutan Cimanuk tersebut sangat mungkin ditujukan kepada daerah Pabean sekarang. Hal ini juga didukung dengan adanya petilasan Syekh Datuk Khapi. Kedatangan Syekh Datuk Khapi di Indramayu berlangsung sesudah tahun 1415. Dari adanya keramik Cina masa dinasti Qing juga memperkuat dugaan ini.

Perkembangan selanjutnya mengarah ke daerah pedalaman yaitu di desa Dermayu sekarang. Di sini terdapat masjid kuna yang diperkirakan sudah berumur lebih dari dua ratus tahun. Bila hal ini benar, maka masjid tersebut dibangun pada sekitar akhir abad XVIII. Suatu koloni Islam sangat memerlukan masjid sebagai sentral segala kegiatan. Dengan adanya masjid ini diduga masyarakat Islam ketika itu sudah banyak. Dari cerita lisan disebutkan bahwa Wiralodra ketika melepaskan daerah Cimanuk dari kekuasaan Sunda (1527) berkedudukan di Dermayu sekarang. Dari sini dapat diambil asumsi bahwa Dermayu sudah merupakan daerah yang mempunyai sistem pemerintahan. Ketika Dermayu berkembang, daerah Pabean masih punya peranan, karena Pabean merupakan gerbang keluar masuk daerah Indramayu.

Ketika bangsa Eropa semakin kuat berkuasa di Jawa, Indramayu mengalami perkembangan yang sangat pesat. Hal ini ditandai dengan semakin banyaknya bangunan yang didirikan bangsa Belanda. Pembangunan besar-besaran terjadi pada masa Daendels (1806-1811). Jaringan prasarana transportasi darat berupa rel kereta api dan jalan raya memperlancar arus transportasi. Indramayu berkembang sebagai kota dagang. Dari daerah pedalaman beras diangkut dengan kereta api atau sarana transportasi darat lainnya hingga ke Indramayu. Dari sini kemudian baru dikirim ke daerah lain melalui laut. Pada masa ini kemungkinan daerah Pabean masih tetap berperan. Kapal-kapal dagang berlabuh di Pabean kemudian diteruskan dengan tongkang menuju pusat kota. Adanya bekas penggilingan padi, stasiun kereta api, dan dam pengatur air di Paoman menunjukkan bahwa barang-barang diangkut dari pedalaman hingga ke Paoman. Dari sini kemudian baru diteruskan ke pelabuhan di Pabean.
Sehingga daerah Paoman berfungsi sebagai pelabuhan di Sungai Cimanuk. Dapat dikatakan sebagai transito barang-barang dagangan. Adanya kantor asisten residen berseberangan dengan Paoman akan memudahkan pengawasan lalulintas perdagangan tersebuit.

Perkembangan ini diikuti pula dengan munculnya pemukiman asing (etnis Arab dan Cina) di daerah Karanganyar, Karangmalang, dan Dermayu. Ketiga lokasi ini masih di sepanjang aliran Sungai Cimanuk. Mapannya etnis Cina di Indramayu ditandai pula dengan dibangunnya klenteng An Tjeng Bio pada tahun 1880. Kehadiran etnis Arab mungkin juga mempengaruhi perkembangan islam di Indramayu. Pembangunan Masjid Agung Indramayu pada tahun 1825 menunjukkan semakin kokohnya Islam. Beberapa ba-ngunan gudang milik bangsa Cina yang meng-hadap ke Sungai Cimanuk serta pendirian masjid agung ditepi Sungai Cimanuk menunjukkan bahwa transportasi air ketika itu masih tetap berperan.

Secara alamiah Indramayu banyak memenuhi persyaratan yang dituntut oleh eksistensi pelabuhan. Lebar serta dalamnya sungai memberi kemudahan bagi transportasi air hingga mencapai pusat kota (daerah Pacinan). Hutan di daerah pedalaman cukup memberi perlindungan terhadap tanah sehingga erosi yang mengakibatkan pendangkalan sangat kecil. Dari aspek teknologis, pada zaman Belanda tersedia kapal keruk yang membersihkan gosong pasir dimuara sungai.

Mundurnya Indramayu lebih dipengaruhi faktor politis dan pemerintahan. Ketika perang dunia ke-2 berkobar, Indramayu dibumihanguskan Belanda. Pihak Belanda yang sebelumnya banyak memperhatikan keberadaan Indramayu sudah tidak lagi. Akhirnya Indramayu terbengkalai dan mengalami masa kemunduran (Dasuki,1977:125128).

Mundurnya Indramayu juga dipengaruhi pesatnya perkembangan di Cirebon. Secara tradisional, Indramayu di bawah kekuasan Cirebon. Pemerintahan Cirebon ketika itu lebih memperhatiakan pelabuhan Cirebon dari pada pelabuhan Indramayu. Akibatnya ketika Indramayu "ditinggalkan" Belanda, pusat perdagangan beralih ke Cirebon.

Kota-kota masa perkembangan Islam di Indonesia pada umumnya terletak di daerah pantai $\mathrm{Hal}$ ini sangat mungkin karena pada masa itu kunci pelayaran dan perdagangan melalui Selat Malaka dan pesisir utara Jawa sebagian besar berada di tangan pedagang-pedagang Muslim. Akibat dari laju perdagangan, kota di sepanjang pantai utara Jawa mengalami perkembangan 
secara spontan. Hal ini pun terlihat pula dalam kasus Indramayu.

Perkembangan kota secara spontan dapat terjadi karena difusi. Dalam hal ini dapat dibedakan antara difusi ekspansi dan difusi penampungan. Proses ekspansi, yaitu suatu proses di mana informasi material dan sebagainya menja-lar meialui populasi dari suatu daerah ke daerah lain. Proses penampungan merupakan suatu pro-ses di mana informasi atau material yang didifu-sikan meninggalkan daerah yang lama dan ber-pindah atau ditampung di daerah yang baru (Bin-tarto dan Surastopo, 1982: 14-15).

Berdasarkan teori tersebut, perkembangan pemukiman di Indramayu cenderung bersifat difusi ekspansi. Mula-mula daerah yang tumbuh yaitu di Pabean kemudian menjalar ke Dermayu. Ketika terjadi perkembangan pada masa Belanda, pusat kota Indramayu sekarang, yaitu di daerah Paoman, Karangmalang, Karanganyar, Lemah Abang, dan Dermayu menjadi pusat kegiatan perdagangan. Pusat kegiatan ini ditandai dengan adanya toponim pasar lawas, kampung Pacinan, Kampung Arab, stasiun kereta api, dan penggilingan padi. Kesemuanya itu menunjukkan bahwa sektor perdagangan memegang peranan. Dalam hal pemerintahan adanya gedung asisten residen yang berseberangan dengan stasiun kereta api memberi kemudahan pengawasan.

\section{KEPUSTAKAAN}

Abdurachman, Paramita R (ed.).1982. Cerbon, Jakarta:Yayasan Mitra Budaya Indonesia, Penerbit Sinar Harapan

Bintarto, $R$ dan Surastopo Hadisumarno.1982. Metode Analisa Geografi Jakarta:LP3ES

Cortessao.Armando.1944. The Suma Oriental of Tomé Pires London: The Hakluyt Society

Dasuki.1977.Sejarah Indramayu,Pemerintah Kabupaten Daerah Tingkat II Indramayu

Djajadiningrat, Hoesein. 1983. Tinjauan Kritis Tentang Sajarah Banten, Jakarta:Penerbit Djambatan, KITLV

Ekadjati, Edi S. 1975. Penyebaran Agama Islam di Jawa Barat, dalam Atja, Sejarah Jawa Barat Dari Masa Prasejarah Hingga Masa Penyebaran Agama Islam, Bandung:Proyek Penunjang Peningkatan Kebudayaan Nasional Propinsi Jawa Barat
Hadisumamo,Surastopo.1985. Manfaat Geomorfologi dan Penginderaan Jauh dalam Kajian Arkeologi makalah pada Ceramah Ilmiah Arkeologi Fak. Sastra UGM (tidak dipublikasikan)

Hourani, A.H. 1970. The Islamic City in The Ligh of Recent Research, dalam The Islamic City A Colloqium, Oxford: Bruno Cassirer

Nas, P.J.M.(ed.).1986. The Indonesian City, Studies in Urban Developmen and Planning, Holland: Foris Publication

Rapoport,Amos. 1986. Tentang Asal-usul Kebu. dayaan Permukiman, dalam Anthony J. Catanese,et al. Pengantar Sejarah Perencanaan Perkotaan Bandung:Intermedia

Saptono,Nanang 1994. Laporan Hasil Penelitian Arkeologi di Kabupaten Indramayu Jawa Barat, Balai Arkeologi Bandung (tidak dipublikasikan)

Soejono,RP (ed.).1990.Jaman Prasejarah di Indonesia, Sejarah Nasional Indonesia I, Jakarta:Departemen Pendidikan dan Kebudayaan, P.N. Balai Pustaka

Tjandrasasmita, Uka(ed.).1984. Jaman Pertumbuhan dan Perkembangan Kerajaan-kerajaan Islam di Indonesia, Sejarah Nasional Indonesia III Jakarta: Departemen Pendidikan dan Kebudayaan, P.N. Balai Pustaka

Sumadio,Bambang (ed.).1990. Jaman Kuna, Sejarah Nasional Indonesia II Jakarta: Departemen Pendidikan dan Kebudayaán, P.N. Balai Pustaka

Wertheim, W.F. 1959. Indonesian Society in Transition, A Study of Social Change, Bandung: Sumur Bandung 